Rev. Int. Contam. Ambie. 36 (4) 795-796, 2020

https://doi.org/10.20937/RICA.54168

\title{
CARTA A LA EDITORA
}

La Editora recibió la siguiente carta en agradecimiento y en memoria del Dr. Rafael Villalobos Pietrini, fundador y Editor de la Revista Internacional de Contaminación Ambiental durante casi 30 años. Creemos importante publicarla como un sencillo homenaje a los dos años de su fallecimento. Agradecemos al Dr. Germán Martínez Alva el haberla remitido.

\section{A la memoria del Maestro Grande}

Al Dr. Rafael de Jesús Villalobos y Pietrini (1936-2018), gracias mi gran Maestro, gracias por confiar en mí e impulsarme con esos artículos científicos para alcanzar el doctorado y ser aceptado en el Sistema Nacional de Investigadores; el tiempo se me estaba pasando por atender prioridades como la salud de mi madre y usted me rescató y reconfortó diciéndome: "adelante que cuentas conmigo, con mi inteligencia, mi persona y poder específico".

El día que lo conocí (aproximadamente 2006) me impactó, tan sereno, impecable, noble y confiado en impulsar a los nuevos jóvenes investigadores; ese día no lo olvidaré jamás, pude ver a un ser magnánimo con una mente privilegiada. Con el tiempo me enseñó a ser formal, a saber desempeñarme como doctor, a pensar en grande y a fijar mi mente en proyectos de investigación que verdaderamente fueran útiles para la sociedad.

Los congresos de la Sociedad Mexicana de Genética eran muy esperados sólo por el hecho de verlo, escucharlo, aprender de usted y recibir sus consejos. Nunca me censuró, siempre usó la palabra con calidez para dirigirme, nunca recibí un gesto desagradable de su persona, y sólo recibí el bien de usted, gracias por la herencia invaluable que me ha dejado.

Usted, un caballero, una persona con don de gente (como decía mi mami), que se ha convertido en inmortal porque vive en la memoria de sus alumnos, en mi memoria, en su obra enorme, en las aulas, en el campo, en los laboratorios, en la gran Universidad.

El cielo es ahora su residencia. Maestro, fue un placer ser su alumno, recibir su orientación y consejos atinados en la investigación científica que atendí y dirigió atinadamente "ahora es mi línea de investigación científica". Seguiré sus pasos porque estoy convencido de lo que hago y el bien que también estoy dejando a este mundo. Gracias por dedicarme su tiempo, por relacionarme con las personas brillantes de ciencia, por compartir su inteligencia de la que no se envanecía.

Siempre lo recordaré, se queda intacto en mi memoria, me duele no verlo más al llegar al Centro de Ciencias de la Atmósfera, pero usted vive... siempre.

\section{LETTER TO THE EDITOR}

The Editor received the following letter in memory and appreciation of Dr. Rafael Villalobos Pietrini, founder and Editor, for almost 30 years, of Revista Internacional de Contaminación Ambiental. We believe it is important to publish it as a humble homage, being now two years of his passing. We acknowledge Dr. Germán Martínez Alva from delivering it.

\section{To the memory of the great teacher}

To Dr. Rafael Villalobos Pietrini (1936-2018). Thanks to my great teacher, thanks for trusting in me and inspiring me to achieve my Ph.D. and to become a member of the Sistema Nacional de Investigadores (National System of Researchers). The time was passing by, for attending priorities as my mother's health, and he rescued and comforted me saying: "go ahead, you can count with me, with my intelligence and my strength". 
The day I know him (around 2006), he impressed me, so calm, impeccable, noble, and with great confidence in helping young researchers; that day I will never forget. I could see a magnanimous being with a privileged mind. With time, he taught me to be formal, to conduct myself as a researcher, to think big and to fix my mind in projects truly useful for society.

The congresses of the Sociedad Mexicana de Genética (Mexican Society of Genetics) were anticipated just to see him, to learn and to receive advice from him. He never censor me, he always use warm words to guide me, I never received a disappointed gesture from him, just great good. Thank you for the invaluable inheritance you left to me.

He, a gentleman, a person with a gift for people (as my mother used to say) has become immortal because he lives in the memory of his students, in my memory, in his great work, in the classrooms, in the field, in the labs, in the great University.

Heaven is now his residence. Beloved and respected teacher: It was a pleasure to be your student, to have your guidance and advice on scientific research, that I tried to follow and you conduct properly because now I have my own research line. I will follow your steps because I am convinced of what I do and I am sure that I am giving something to this world. Thank you for dedicating me your time, for introducing me to brilliant people in science, for sharing with me your intelligence, of which you never became vain.

I will always remember you, you remain intact in my memory, it hurts not to see you when arriving at the Centro de Ciencias de la Atmósfera, but you live... forever.

Dr. Germán Martínez Alva 